\title{
Last Year of Contact
}

National Cancer Institute

\section{Source}

National Cancer Institute. Last Year of Contact. NCI Thesaurus. Code C159713.

An indication of the last year during which a subject was seen or spoken with. 